\title{
FLORA MALESIANA
}

\section{SERIES I - SPERMATOPHYTA}

Flowering Plants

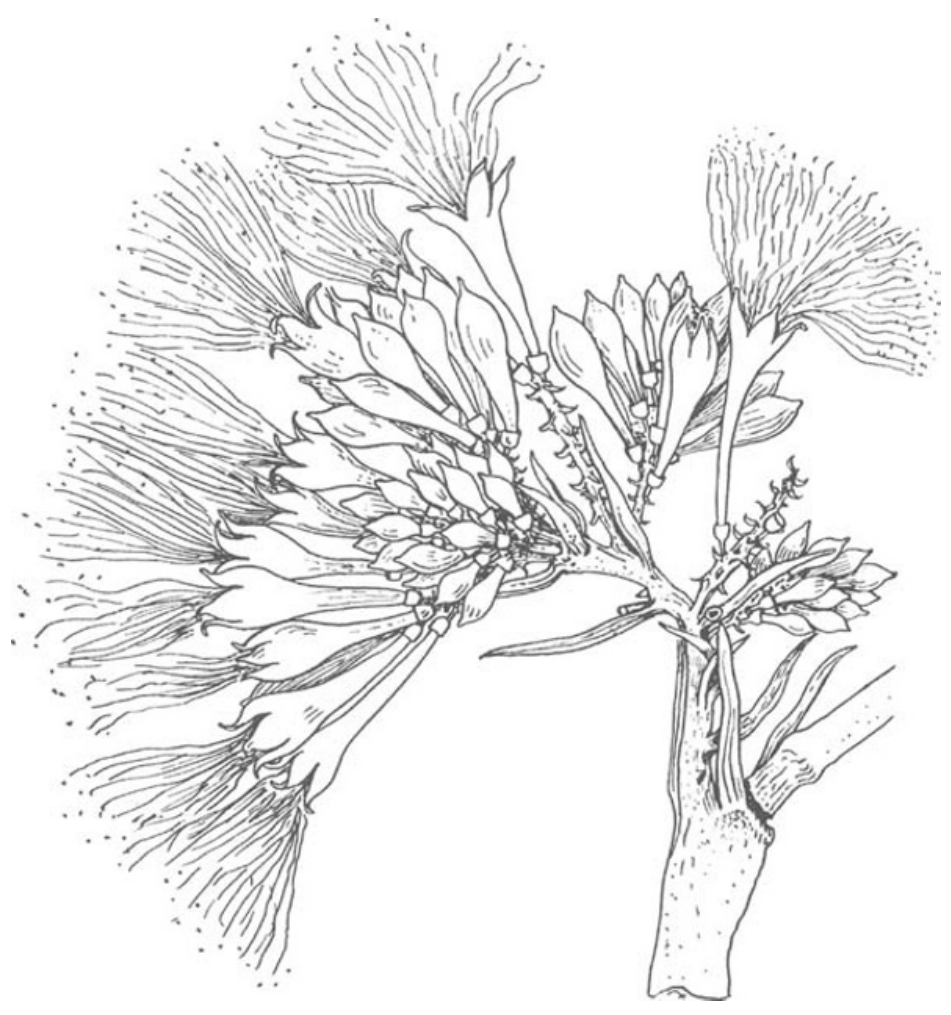

Volume 11, part 1

Mimosaceae (Leguminosae-Mimosoideae)

by I. C. Nielsen

(treatment of Parkia by H.C. Fortune Hopkins) 


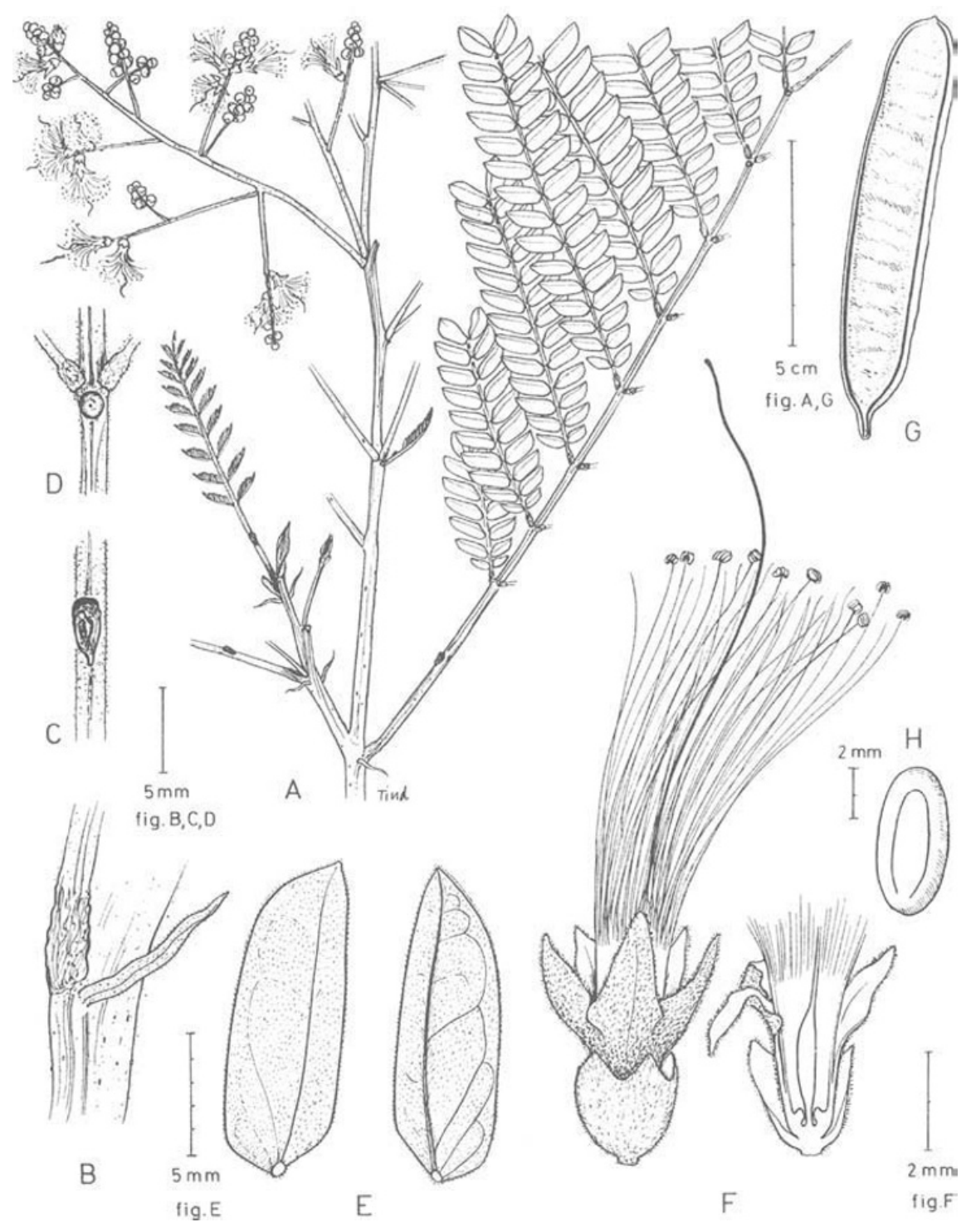

Line-drawing given on page 152 of this Flora Malesiana instalment:

Paraserianthes falcataria (L.) Nielsen subsp. falcataria. A. Flowering branch; B. stipule; C. nectary on petiole; D. nectary on rachis; E. leaflets seen from above (left) and from below (right); F. flower; G. pod; H. seed (A-F: Sinclair S.n., Apr. 1951; G, H: Meijer 7198). - The cover of this leaflet has an illustration of the inflorescence and flowers of Archidendron nervosum De Wit. 


\section{FLORA MALESIANA}

announces publication of

Volume 11 (1) of the Seed Plants series, comprising the

\section{Mimosaceae \\ (Leguminosae-Mimosoideae)}

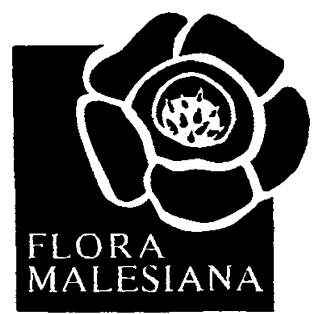

The author, I.C. Nielsen, has over the years made many contributions to the systematic knowledge of the family worldwide. The treatment of the genus Parkia with 5 species has been contributed by H.C. Fortune Hopkins.

\section{About the contents:}

- Malesia has c. 150 native and naturalized species of Mimosaceae. There are 19 genera represented in Malesia, 15 of which are native. The region has only one endemic genus (Wallaceodendron). Apart from the revision of wild representatives, 45 cultivated species are enumerated.

- Two identification keys to the genera are provided, the longest one using vegetative characters along with flower and fruit characters, the other one restricted to flower, fruit, and seed characters. The seven most commonly cultivated genera are included in these keys. All genera except the monotypic ones have their keys to the species, sometimes two.

- The treatment follows the established pattern of Flora Malesiana, a Flora that aims at being a user-friendly means of identification and providing a survey of general botanical knowledge with literature references on family, genera, and species.

- General chapters on family level include among others Fruit, seed, and seedling morphology, Vegetative anatomy (by P. Baas), Palynology (by R.W.J.M. van der Ham), and Phytochemistry (by R. Hegnauer). The last-mentioned chapter is more elaborate (13 pages, including the list of references) than usual in Flora Malesiana since volume 11 of the author's multivolume book 'Chemotaxonomie der Pflanzen', which will contain the Leguminosae, has not yet been published.

- Illustration is by 37 line-drawings (11 full-page) and distribution maps.

- For detailed bibliographic information on this 226 pages instalment of the prestigious Flora Malesiana series, see the order form at the back of this leaflet, where also the price is given.

- The next part of Flora Malesiana series I will contain revisions of Amaryllidaceae, Coriariaceae, Pentastemonaceae, Rosaceae, and Stemonaceae. Publication is planned medio 1993. 


\section{ORDER FORM Please return to: Publications Department}

Rijksherbarium / Hortus Botanicus

P.O. Box 9514

2300 RA Leiden

Name / Institution:

The Netherlands

\section{Address:}

\section{Country:}

would like to receive

\section{Flora Malesiana, series I, volume 11, part 1}

Mimosaceae (Leguminosae-Mimosoideae)

by I. C. Nielsen

1992, 226 pp., illus. - ISBN 90-71236-16-1 - Dfl. 75.00 per copy

\begin{tabular}{rlr} 
Quantity $\ldots$. & Dfl. $\ldots \ldots \ldots$ \\
Banking costs & Dfl. & 20.00 \\
Total & Dfl. $\ldots \ldots \ldots$ \\
\hline
\end{tabular}

Please enter our standing order for Flora Malesiana

$\square$ Both series

Series I (Spermatophyta), starting with Volume 11

- Series II (Pteridophyta), starting with Volume 2

Conditions for sale: list price plus Dfl. 20.00 banking costs (unless paid by Eurocheque, Eurocard/MasterCard, or international postal money order).

Discount on list price for booksellers and subscription agencies $20 \%$.

Payment by Eurocard / MasterCard - I authorise you to charge my Eurocard / MasterCard

Name Cardholder

Address:
Card No.

Expiry Date

Date

Signature

Bij bestellingen binnen Nederland wordt $6 \%$ BTW berekend. For orders in the Netherlands $6 \%$ VAT will be charged. 


\title{
IN VITRO WOOD FORMATION IN 'CHIPS' FROM MERCHANTABLE STEM REGIONS OF LARIX LARICINA
}

\author{
by \\ R. A. Savidge \\ Department of Forest Resources, University of New Brunswick, Fredericton, NB, \\ E3B 6C2, Canada
}

\section{Summary}

Stem 'chips' from large-diameter stem regions of Larix laricina were produced free of contaminating organisms. These chips, consisting of dormant vascular cambium sandwiched intact between mature xylem and phloem, were grown as in vitro cultures on the surface of an agar medium that supports apparently normal cambial cell division and xylogenesis. It was determined that auxin (1-naphthalene acetic acid) together with nutrients at low concentrations in the medium was essential for cambial growth, whether chips were grown in continuous light or darkness. Fusiform cambial cells underwent successive periclinal divisions to produce radial files of enlarged, bordered-pitted, secondarywalled, lignified and autolysed earlywood tracheids. As many as 20 new tracheids per radial file were produced, and $>95 \%$ of these were autolysed after 35 days of culture.

Chips from stems harvested from October to April were competent for vigorous surface callus production on all dates except early April. In contrast, competence for wood formation within chips varied seasonally reaching a maximum in early April, one month before natural cambial reactivation. Chips which were competent for callus production but not for cambial growth produced granulated friable callus. Chips which were competent for both callus production and secondary growth produced compact striated callus.

Key words: Auxin, bordered-pit development, cambial growth, earlywood production, tracheid differentiation, xylogenesis, phytohormones.

\section{Introduction}

The merchantable wood of interest to industrial forestry is derived from cambia older than three years. However, current knowledge about the physiology of wood formation comes principally from experiments performed with either seedlings or young stem cuttings collected from older trees (Little \& Savidge 1987). Investigations done with conifer stem segments of varied ages (i.e., years) revealed that findings on auxin regulation made using one-year-old stem material could not be repeated when material older than two years was used (Zajączkowski 1973; Savidge \& Wareing 1981b; Savidge 1983; Little \& Sundberg 1991). Moreover, the accumulated data indicates that the short season of cambial growth, in spring and early summer, of temperate-zone conifers cannot be explained simply in terms of auxin and sucrose import from the shoot system and water and nutrient import from the root system (Savidge \& Wareing 1981b; Little \& Savidge 1987; Savidge 1991). Other factors appear to be of equal or possibly even greater regulatory importance (Savidge \& Wareing 1981a; Savidge 1983; 1988; 1989); however, these factors remain to be fully investigated and characterised.

When the physiology of wood formation is correctly known it should be possible to model diameter growth in vitro as it occurs in situ, regardless of cambial age. The cambium in fact was one of the first higher plant tissues to be cultured in vitro (Gautheret 1934), and progress has been made with both hardwoods (Gautheret 1959; Sussex \& Clutter 1959; Jacquiot 1964; Brown 1964) and conifers 
Table 1. Composition of culture medium supporting cambial growth in Larix laricina. (milligrams per litre of double-distilled water)

Inorganic components

$\begin{array}{lc}\mathrm{KNO}_{3} & 475.0 \\ \mathrm{NH}_{4} \mathrm{NO}_{3} & 412.0 \\ \mathrm{CaCl}_{2} \cdot 2 \mathrm{H}_{2} \mathrm{O} & 110.0 \\ \mathrm{MgSO}_{4} \cdot 7 \mathrm{H}_{2} \mathrm{O} & 93.0 \\ \mathrm{KH}_{2} \mathrm{PO}_{4} & 43.0 \\ \mathrm{FeSO}_{4} \cdot 7 \mathrm{H} 2 \mathrm{O} & 7.00 \\ \mathrm{MnSO}_{4} \cdot 4 \mathrm{H}_{2} \mathrm{O} & 6.00 \\ \mathrm{H}_{3} \mathrm{BO}_{3} & 1.00 \\ \mathrm{KI} & 0.200 \\ \mathrm{Na}_{2} \mathrm{MoO}_{4} & 0.060 \\ \mathrm{CuSO}_{4} \cdot 5 \mathrm{H}_{2} \mathrm{O} & 0.060 \\ \mathrm{CoCl}_{2} \cdot 6 \mathrm{H}_{2} \mathrm{O} & 0.060\end{array}$

Organic components

myo-Inostol 25.0

Nicotinic acid $\quad 0.125$

Pyridoxine $\mathrm{HCl} \quad 0.125$

Thiamine $\mathrm{HCl} \quad 0.05$

Glycine $\quad 0.50$

$\mathrm{Na}_{2}$ EDTA $\quad 9.30$

D-Glucose $\quad 40000$

Auxin (1-naphthalene acetic acid) $\quad 0.50$

Medium adjusted to $\mathrm{pH} 5.8(0.1 \mathrm{~N} \mathrm{KOH})$ before adding agar (Difco Bacto-agar, $0.8 \% \mathrm{w} / \mathrm{v}$ ) and autoclaving at $121^{\circ} \mathrm{C}$ and $140 \mathrm{kPa}$ for $20 \mathrm{~min}$.

(Ball 1950; Wacek et al. 1954; Reinert \& White 1956; Geissbühler \& Skoog 1957; Zajączkowski 1973; Savidge \& Wareing 1981b; Savidge 1983; Sheriff 1983; Liłkovà 1985; Ramsden \& Northcote 1987) in terms of discovering methods and media that will support cambial activity and tracheid differentiation in vitro. But a reliable and satisfactory protocol for simulating in vivo wood formation using explants from large-diameter $(\geq 6 \mathrm{~cm})$ merchantable stem regions of conifers has nevertheless remained wanting.

The simplest procedure for growing the cambium in vitro is undoubtedly to peel the bark and explant thin strips of cambium from the inner bark face (White 1954). However, with conifers this approach invariably results in proliferation of the rays and/or adjoining phloem parenchyma, with no cell-division activity occurring in fusiform cambial cells for reasons which remain unclear (Savidge 1983). Moreover, numerous reports suggest that cambial cells cultured in this way lose competence for xylogenesis (White 1954; Geissbühler \& Skoog 1957; Gautheret 1959; Jacquiot 1964; Savidge 1983, 1989), the work of Ball (1950) with callus derived from burl shoots of Sequoia sempervirens being a notable exception. Despite the claim of lignification in cambial explants of Pinus strobus (Hasegawa et al. 1960), no evidence has been seen for xylogenesis in cultures of cambial strips taken from mature stem regions of that or any other conifer species (Savidge 1983, 1989). Until these problems are solved, culture of cambial strips appears not to be a useful system for simulating either cambial growth or xylogenesis. Here a method for inducing earlywood formation using dormant explants from eightyear-old stem material of 10- to 30-year-old forest-grown tamarack trees is reported.

\section{Materials and Methods}

Trees - Tamarack [Larix laricina (Du Roi) K. Koch] approximately 20 years old and six to eight metres in height were felled in the University of New Brunswick Forest (Fredericton, NB, Canada) on several dates from October to April, as indicated in the figures. After delimbing, an eight-year-old stem segment was sawn from the main axis of the tree and transferred back to the laboratory for chip preparation. Three trees were selected on each date.

Chip preparation - After brushing away loose bark, the bark surface was washed by hand with detergent (Sparkleen, Fisher Sci.) and warm tap water, rinsing the surface thoroughly with running tap water after washing. Using a razor-sharp knife, outer rhytidome 
was pared from the entire surface to the level of crushed phloem, ensuring that no resin cysts remained. The exposed phloem surface was washed with cold flowing tap water; then the segment was drained of excess water and stood upright in a large crystallising dish set on the surface of a horizontal laminar flow cabinet. Absolute ethanol was poured over the segment and, after decanting excess ethanol from the crystallising dish, the surface of the segment was ignited and permitted to burn until the flame dyed. During the flame sterilisation process, the crystallising dish was rotated slowly through $180^{\circ}$.

Using a flame-sterilised razor-sharp allmetal knife, 'stem chips' $(2-3 \mathrm{~cm}$ axial $\times 2$ $\mathrm{cm}$ tangential $\times 0.5 \mathrm{~cm}$ radial) containing dormant cambium sandwiched between mature phloem and xylem were cut from each segment and transferred such that the xylem surface was in contact with defined nutrient medium.

Culture medium - Table 1 presents the composition of the culture medium that was used, the medium being a modification of that of Allen et al. (1988). When preparing a litre or more of medium, components at $\geq 25$ $\mathrm{mg} \mathrm{1^{-1 }}$ were weighed directly. Components at lower concentrations were made up as stock solutions, adding appropriate aliquots volumetrically. 1-Naphthalene acetic acid (NAA, Sigma Chemical Co.) was added at $0.5 \mathrm{mg} \mathrm{l}^{-1}$ unless otherwise indicated. Before autoclaving $\left(121^{\circ} \mathrm{C}, 140 \mathrm{kPa}, 20 \mathrm{~min}\right)$, the medium was adjusted to $\mathrm{pH} 5.8$ with 0.1 $\mathrm{N} \mathrm{KOH}$, and agar $(0.8 \% \mathrm{w} / \mathrm{v}$, Difco Bactoagar) was added. Sterilised medium was poured into pre-sterilised plastic dishes (Fisher Sci.) to a depth of 3-5 mm. Following explanting, plates were sealed with parafilm (Fisher Sci.).

Culture conditions - Chips were grown in continuous light (ordinary white fluorescent, $12 \mathrm{~W} \mathrm{~m}^{-2}$ ) or in darkness at a constant temperature of $25^{\circ} \mathrm{C}$. After the elapse of 35 days, chips were fixed in ethanol-acetic acidwater $(70 / 5 / 25$ by vol).

Visual assessments - At the end of the culture period, the amount of surface callus generated from the phloem-cambial region on the external surface of each chip was estimated. Presence of no macroscopically visible callus was given a value of zero. Values of 1 , 2 , and 3 (Fig. 1) corresponded approximately to 1,2 , and $3 \mathrm{~mm}$ thicknesses of callus, respectively.

Microscopy - Transverse or radial sections were cut by hand with a razor blade and mounted in tap water. Brightfield, Nomarski, and incident UV autofluorescence microscopy (B-1 filter: bandpass $450-495 \mathrm{~nm}$, longpass $520 \mathrm{~nm}$ ) were done on unstained sections with a Reichart Polyvar 2. Tracheid numbers per radial file were counted in transverse section; cells of the cambial zone and enlarged cambial derivatives having only primary walls were not counted.

\section{Results}

Media investigated for their ability to support the growth of chips included those of Murashige and Skoog (1962), Harvey and Grasham (1969), Reinert and White (1956), Schenk and Hildebrandt (1972) as modified by Reilly and Washer (1977), and Allen et al. (1988). Of these, the medium of Allen et al. (1988) was the only one that supported cambial activity and wood formation in chips; however, the medium of Reilly and Washer supported some callus growth. The medium of Allen et al. (1988) contains Evan's whale peptone (no longer available: E.A. Allen, personal communication) as well as soytone; hence, it is an imperfectly defined medium. Subsequent investigations showed that peptone and soytone could be removed; hence, the medium was simplified to that described in Table 1 without loss of the cambial growth response. Neither callus nor cambial growth occurred when chips were grown on the medium of Table 1 but with $\mathrm{KNO}_{3}$ at $2500 \mathrm{mg}$ $1^{-1}$, a level characteristic of many higher plant culture media.

The cambium was dormant on every date; hence, the latewood boundary was used as a marker of the extent of cambial growth. After 5 weeks of culture (medium of Table 1), $>90 \%$ of chips remained free of contamination irrespective of when primary explants were made. Competence for peripheral callus growth (Fig. 1) extended from October through March, but callus was not produced by April explants. Callus on chips grown in 


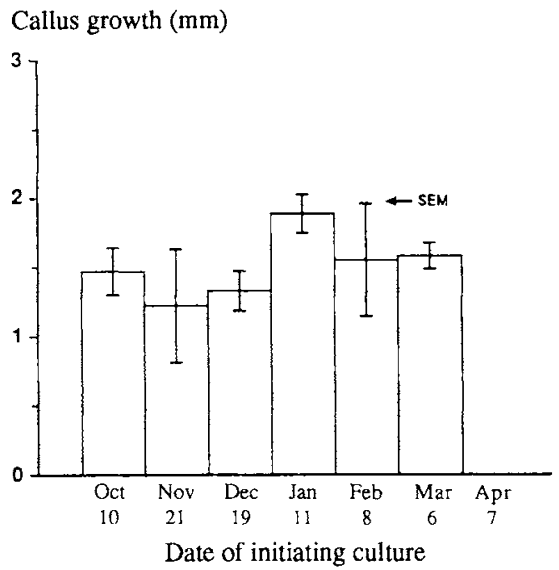

Fig. 1. Callus growth on the surface of chips as a function of date of explanting. SEM: standard error of the mean (means of three genotypes). No callus growth was associated with April explants.

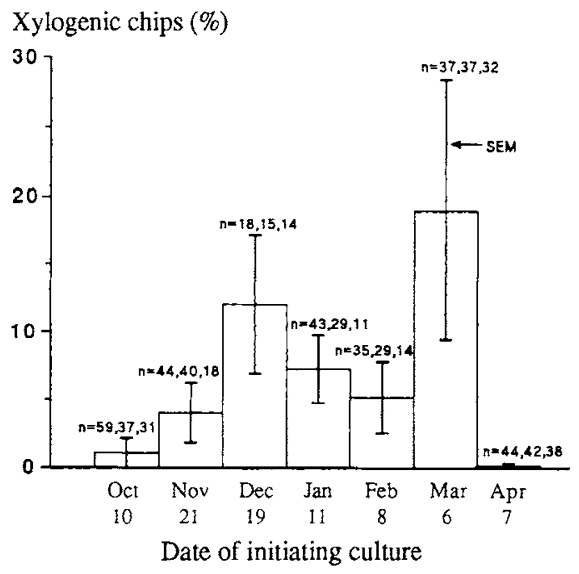

Fig. 3. Capability for wood formation in chips as a function of date of explanting. All cultures were grown for 35 days. SEM: standard error of mean (means of three genotypes). $\mathrm{n}$ : total number of chips cultured per genotype.
Mean tracheid number per radial file

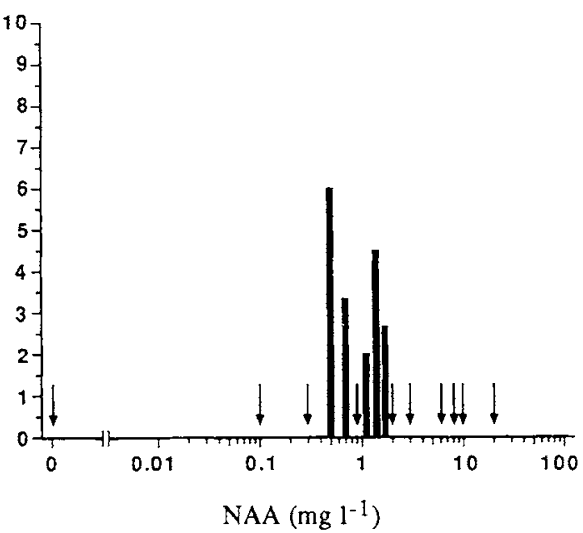

Fig. 2. Tracheid number per radial file (xylogenic chips only, means of three genotypes) produced within chips in response to varied concentrations of NAA. The arrows indicate NAA concentrations yielding no cambial growth. Culture period: Feburary 14-April 5.

Xylogenic response (tracheids per radial file)

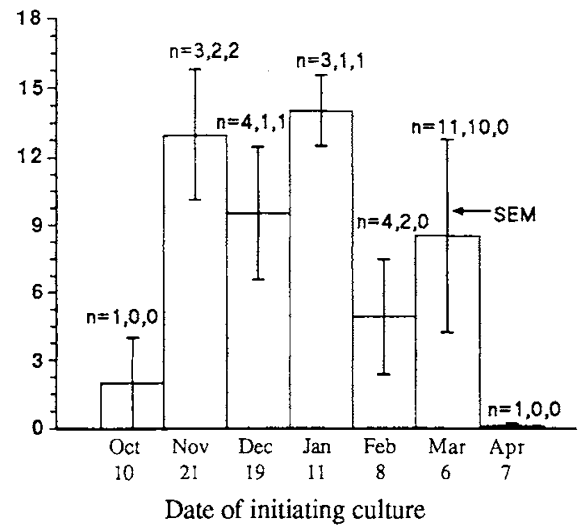

Fig. 4. Tracheid production (cells per radial file) in chips as a function of the date of initiating cultures. All cultures were grown for 35 days. SEM: standard error of mean (means of three genotypes). $\mathrm{n}$ : number of xylogenic chips per genotype. continuous light was green, whereas that of chips grown in darkness was pale brown. Cambia of chips having green callus appeared slightly more vigorous, in terms of both the extent of callus growth and number of tracheids produced, than those grown in darkness; however, using bright-field, Nomarski, and autofluorescence microscopy, no qualitative differences between xylem produced in dark-grown chips and that produced in light- 


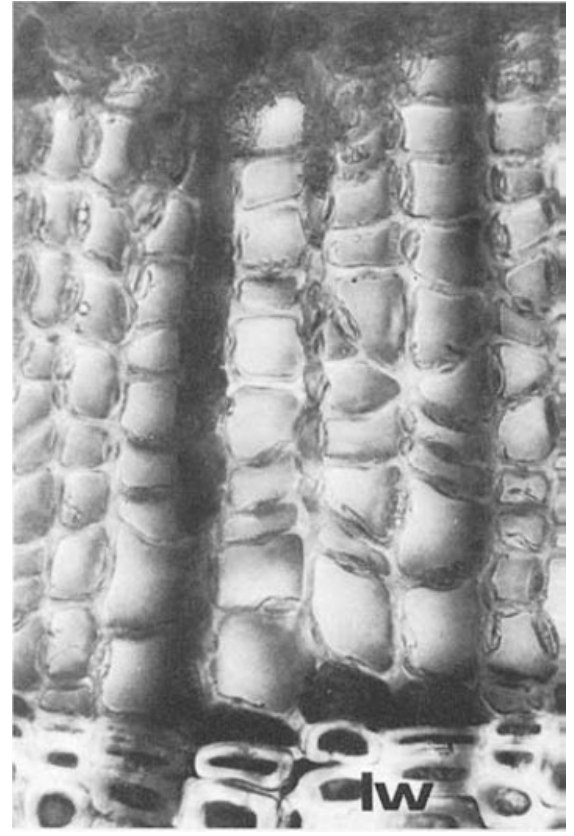

Fig. 5. Transverse hand section showing new xylem (unstained) produced in vitro, together with a few tiers of thick-walled latewood (lw), as viewed by bright-field microscopy. Note that bordered pits are abundantly present in tangential as well as radial walls of the earlywood. Some of the first produced earlywood cells have inclusions. Two rays (dark streaks) are evident.

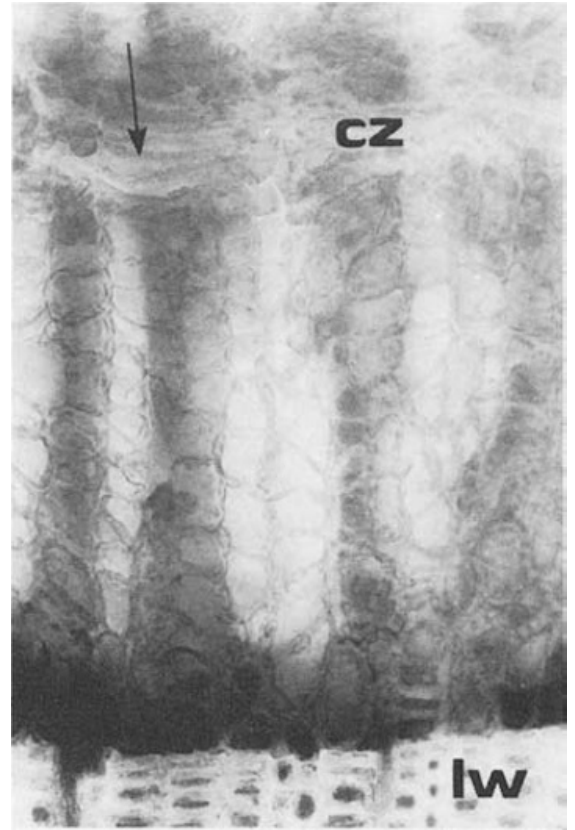

Fig. 6. Transverse hand section showing new xylem (unstained) produced in vitro, together with a few tiers of thick-walled latewood (lw) and cambium (cz) as viewed by bright-field microscopy. A loss of normal axial polarity in fusiform cambial cells and their derivatives is evident (arrow). Dark cells at the latewoodearlywood boundary are a wound response. grown chips were seen. The callus associated with xylogeric chips, whether grown in light or darkness, was invariably compact and axially striated. In contrast, the callus produced by non-xylogenic chips was invariably granular and friable.

Growth response of the cambium within chips to a series of 1-naphthalene acetic acid (NAA) concentrations is shown in Figure 2. NAA between 0.5 and $1.7 \mathrm{mg} \mathrm{l}^{-1}$ supported cambial cell-division activity and wood formation. Higher and lower NAA concentrations yielded no callus or cambial growth. Hence, an NAA concentration of $0.5 \mathrm{mg} \mathrm{l}^{-1}$ was chosen for all subsequent investigations.

Competence of the cambium within the chip for xylogenesis varied depending on the harvest date. The proportion of chips producing new xylem appeared to be greater when explanting was done during December and March than on other dates (Fig. 3); however, it should be noted that the sample size for the December cultures was small and the standard error of the mean large.

Figure 4 shows mean tracheid number per radial file produced by xylogenic chips. Although the data of Figure 3 suggest that a higher proportion of explanted chips are likely to produce new wood when explanted in December or March, the data of Figure 4 indicate that when explanted in November or January, chips which are competent for wood formation will produce the greater number of tracheids per radial file. 
No counts of bordered-pit frequency were made; however, bordered-pit number was clearly elevated over that which occurs in situ within the tree stem, and bordered pits were often seen in tangential as well as radial walls (Fig. 5).

The continuity of radial files was usually maintained as fusiform cambial cells underwent successive periclinal divisions to produce new tracheids (Fig. 5). On the other hand, a change in polarity of fusiform cambial cells was clearly evident in some chips (Fig. 6). Radial file doubling, evidence for anticlinal cell-division activity, was occasionally observed in both ray and fusiform cambial cells.

Axial resin canals were not seen in either growing or non-growing chips. The first one to two cells per radial file to differentiate adjacent to latewood retained their protoplasmic contents, giving the impression of axial parenchyma (Figs. 5, 6). Similar cells differentiated within non-growing cambium, suggesting that this was strictly a response to wounding.

Incident UV illumination of untreated hand sections of chip-produced tracheids yielded a yellow-green fluorescence, identical to autofluorescence of lignin in xylem produced within the tree stem before culturing, in walls of new tracheids but not in those of ray cells. The presence of crystalline microfibrils in cell walls was confirmed using Nomarski optics.

\section{Discussion}

The matter of how wood formation in conifers is regulated remains quite unresolved; however, certain principles are emerging (Savidge \& Wareing 1981b; Little \& Savidge 1987; Savidge 1988, 1990). Excepting oneyear-old or younger stem material, exogenous auxin by itself is insufficient to promote cambial cell-division activity, primary-wall radial expansion of cambial derivatives, or tracheid differentiation; however, a continuing supply of auxin nevertheless serves to maintain the elongated shape of fusiform cambial cells and their nuclei (Savidge \& Wareing 1981b; Savidge 1983). Cambial growth in young stem segments (cut from the tree) in response to exogenous auxin is strongly reduced and may be completely eliminated if leaves are removed (Savidge \& Wareing 1981a; Savidge
1983). In two-year-old or older stem segments, apically applied auxin is required for maintenance of fusiform cambial cell morphology; however, cambial activity and wood formation do not occur unless intact leaves are present (Savidge \& Wareing 1981a; Savidge 1983). In disbudded stem cuttings (or trees) having mature leaves intact, exogenous auxin is not essential for occurrence of cambial growth; however, auxin applications modify where the growth response occurs. In the absence of applied auxin, maximal growth occurs at the base of the segment (or tree), whereas growth is redistributed toward the application site when exogenous auxin is used (Savidge 1983). In naturally defoliated stem segments (or trees) older than two years that have been treated with auxin, little if any cambial growth occurs (Zajączkowski 1973; Savidge \& Wareing 1981b; Savidge 1983; Little \& Sundberg 1991).

There is also evidence that older cambia are biochemically less competent than twoyear-old or younger cambia. During growth within the intact tree, conifer cambia in general produce large amounts of ethylene, but in isolated stem segments cambia fewer than two years of age produce considerably more ethylene than older cambia (Savidge 1988). It is well known that 1-aminocyclopropane-1carboxylic acid (ACC) synthesis in higher plants is stimulated by auxin and that this is associated with elevated ethylene emanation (Savidge et al. 1983). But in isolated conifer cambia older than two years, auxin by itself does not promote increased ethylene emanation; rather, exogenous auxin and exogenous ACC are both essential to achieve emanated ethylene levels similar to those occurring in vivo (Savidge 1988).

In the specific case of tamarack, when oneyear-old stem cuttings are harvested in late winter, disbudded, and stood upright in water in a warm lighted environment, limited cambial cell-division activity and tracheid differentiation occurs in response to exogenous auxin being applied to their apical ends. When three-year-old and older tamarack stem segments are similarly treated, new needles on short shoots elongate for several centimetres; however, no cambial activity or tracheid production occurs in the segments, the only ana- 
tomical effect of auxin being to maintain the polar forms of the fusiform cambial cells and their nuclei, as noted above (R.A. Savidge, unpublished). It follows that tamarack stems older than two years have sufficient reserves in their stems to support needle elongation in vivo, but despite a continuing supply of auxin to the cambium these reserves are not allocated to cambial growth.

Previous studies revealed that during dormancy, cambial content of endogenous sucrose in older stem regions of tamarack was reduced, as would be expected for a deciduous conifer; however, after a winter of leaflessness, cambial sucrose levels remained above $100 \mathrm{mg} \mathrm{g}^{-1} \mathrm{fw}$, suggesting that carbohydrate levels in isolated stem segments probably are not limiting for cambial reactivation (Savidge 1991). This interpretation was supported by the observation that when only glucose was removed from the medium of Table 1 , callus and cambial growth occurred in chips, although to a decreased extent (data not shown).

Although the cambium of three-year-old and older tamarack stem segments shows no growth response to exogenous auxin, the cambium in eight-year-old stem chips grew and generated cells that underwent complete differentiation into apparently normal earlywood tracheids. Auxin was clearly essential for cambial growth and tracheid differentiation in chips, and the inability of applied auxin to promote growth in isolated stem segments of similar age suggests that one or more additional components of the medium (Table 1) must be at least equally as essential as auxin in order for cambial growth to occur. This reasoning was substantiated by growing chips on agar containing NAA as the only additive: this treatment induced neither callus nor cambial growth (data not shown).

If left intact within the tree, the cambia explanted within eight-year-old chips would very probably have produced a radial thickness of wood approaching $8-10 \mathrm{~mm}$. This interpretation is based upon observations of cambial growth rate in immediately preceding years (data not shown). But grown in vitro, chip cambia never yielded more than $1 \mathrm{~mm}$ of earlywood tracheids, and subculturing did not lead to continuing growth or latewood production (data not shown). This suggests that in addition to the constituents of the medium (Table 1), there may be one or more growth factors harboured within the tissue of the chip which enabled the observed growth responses and which, when exhausted, resulted in cambial dormancy. A number of stem-transmissible factors have been documented for Larix and other coniferous species (Franz \& Meier 1967, 1969; Kretz 1973); however, it remains to be determined which are essential for diameter growth.

A critical thickness of crushed and noncrushed phloem appeared essential for successful growth of the chips. Chips having a thick bark layer exhibiting resin cysts on the bark surface were associated with frequent outgrowth of fungi and bacteria, and cambial growth generally was inhibited in contaminated chips. Chips having only three or fewer layers of crushed phloem were apparently free of microorganisms but rarely exhibited cambial growth, presumably because the cambium had been either killed or heat shocked during the flame-sterilisation procedure. Chips having bark free of resin cysts with 1-2 mm of phloem overlaying the cambium exhibited best cambial growth.

In chips capable of growth, differentiation of fusiform cambial cells into axial parenchyma was an early cambial response to being removed from the stem and placed into culture. This as well as development of axial traumatic resin-canals in earlywood are cambial responses which commonly occur as apparently direct responses to wounding of nearby stem tissues in Pinaceae (Savidge \& Farrar 1984). Interestingly, although axial resin canals are a common feature of Larix xylem, traumatic resin canals were never seen in chip earlywood, suggesting that some factor of the culture conditions inhibited their formation. Additional research may reveal methods to induce or eliminate wound responses.

Ray-cell swelling, conversion of uniseriate rays to biseriate rays through cell division, and changes in cambial fusiform-cell polarity were all noted in the new xylem. These anatomical changes probably are a result of alterations in internal pressure relations rather than direct responses to physical wounding. Maintenance of physical contact between 
cambial cells and those of mature xylem and phloem within the chip interior probably was a factor enabling fusiform cambial cells to divide normally in the periclinal plane (Brown 1964; Savidge 1983, 1985; Makino et al. 1983), enabling the maintenance of cambialcell form and radial-file continuity.

Various methods of preparing the cambium for in vitro culture were described by Gautheret (1959). The method used in this study was similar to a method first reported by Gioelli (1938). This method enables culture of intact cambium with minimal cell wounding except at the peripheries of the chip. Unfortunately, this also has several drawbacks: a razor-sharp knife must be used forcibly and there is always the danger of it slipping, making the extraction of chips arduous and stressful. In addition, the work is strenuous and tends to blister the uncallused hand. For these reasons, alternative preparation procedures were investigated. When stem segments were cut into a series of disks, as described by White (1954, the preparation of cambial cultures from small-diameter branches), surface sterilised, and cambium sandwiched intact between mature xylem and phloem removed, the explants could readily and safely be cleaved from the disks; however, neither callus nor cambial growth occurred in these explants, suggesting that they were dead.

In conclusion, this research has demonstrated that it is possible to simulate earlywood formation in vitro as it occurs in merchantable stem regions of tamarack, provided an auxin is present in the medium. Experimental simulation of complete annual ring formation remains to be achieved, evidently because certain factors essential for ongoing cambial growth remain to be discovered. In future investigations, it will be of interest to discover what effects variations in physical environment and/or culture medium composition have on anatomical, chemical and physical properties of phloem, cambium and xylem.

\section{Acknowledgements}

Ruth Welburn and Mathew Leitch prepared culture media, and Mr. Leitch assisted in chip preparation and microscopy. This research was funded by the Natural Sciences and Engineering Research Council of Canada. A gift of Evan's peptone was received from Dr. E. A. Allen.

\section{References}

Allen, E.A., P.V. Blenis \& Y. Hiratsuka. 1988. Axenic culture of Endocronartium harknessii. Mycologia 80: 120-123.

Ball, E. 1950. Differentiation in a callus culture of Sequoia sempervirens. Growth 14: 295-325.

Brown, C.L. 1964. The influence of external pressure on the differentiation of cells and tissues cultured in vitro. In: M.H. Zimmermann (ed.), The formation of wood in forest trees: 389-404. Academic Press.

Franz, M. \& H. Meier. 1967. Die niedermolekularen Kohlenhydrate im Cambialsaft von Larix decidua Mill. Planta (Berl.) 73: $155-160$.

Franz, M. \& H. Meier. 1969. Die organischen Säuren im Cambialsaft von Larix decidua Mill. Planta (Berl.) 85: 202-208.

Gautheret, R.J. 1934. Culture du tissu cambial. C. R. Ac. Sc. 198: 2195-2196.

Gautheret, R.J. 1959. La culture des tissus végétaux. Techniques et réalisations. Masson, Paris.

Geissbühler, H. \& F. Skoog. 1957. Comments on the application of plant tissue cultivation to propagation of forest trees. TAPPI 40: 257-262.

Gioelli, F. 1938. Morfologia, istologia, fisiologia e fisiopatologia di meristemi secondari in vitro. Att. Ac. Sc. Ferrara 16: 1-87.

Harvey, A.E. \& J.L. Grasham. 1969. Procedures and media for obtaining tissue cultures of 12 conifer species. Can. J. Bot. 47: 547-549.

Hasegawa, M., T. Higuchi \& H. Ishikawa. 1960. Formation of lignin in tissue culture of Pinus strobus. Plant \& Cell Physiol. 1: 173-182.

Jacquiot, C. 1964. Application de la technique de culture des tissus végétaux l'étude de quelques problèmes de la physiologie du l'arbre. Ann. Sci. For. 21: 317-473.'

Kretz, A. 1973. Zucker, Cyclite und organische Säuren des Cambialsaftes von Pinus silvestris L., Picea abies Karst. und Abies alba Mill. Planta (Berl.) 110: 1-14. 
Lißkovà, D. 1985. Regulation of tracheid differentiation by various auxins in spruce tissue culture. Biologia (Bratislava) 40: 431-436.

Little, C.H.A. \& R.A. Savidge. 1987. The role of plant growth regulators in forest tree cambial growth. Plant Growth Regulation 6: 137-169.

Little, C.H. A. \& B. Sundberg. 1991. Tracheid production in response to indole-3acetic acid varies with internode age in Pinus sylvestris stems. Trees 5: 101-106.

Makino, R., H. Kuroda, \& K. Shimaji. 1983. Callus formation, and effects of applied pressure to the cultured cambial explant of sugi (Cryptomeria japonica). Wood Res. 0 (69): $1-11$.

Murashige, T. \& F. Skoog. 1962. A revised medium for rapid growth and bioassays with tobacco tissue culture. Physiol. Plant. 15: 473-497.

Ramsden, L. \& D.H. Northcote. 1987. Tracheid formation in cultures of pine Pinus sylvestris. J. Cell Sci. 88: 467-474.

Reilly, K.J. \& J. Washer. 1977. Vegetative propagation of radiata pine by tissue culture: Plantlet formation from embryonic tissue. New Zeal. J. For. Sci. 7: 199-206.

Reinert, J. \& P.R. White. 1956. The cultivation in vitro of tumor tissues and normal tissues of Picea glauca. Physiol. Plant. 9: 177-189.

Savidge, R.A. 1983. The role of plant hormones in higher plant cellular differentiation. II. Experiments with the vascular cambium, and sclereid and tracheid differentiation in the pine, Pinus contorta. Histochem. J. 15: 447-466.

Savidge, R.A. 1985. Prospects for manipulating vascular-cambium productivity and xylem-cell differentiation. In: M.G.R. Cannell \& J.E. Jackson (eds.), Attributes of trees as crop plants: 208-227. Inst. Terr. Ecol., Monks Wood Exper. Station, Abbots Ripton, Huntingdon, England.

Savidge, R. A. 1988. Auxin and ethylene regulation of cambial growth in forest trees. Tree Physiol. 4: 401-414.

Savidge, R.A. 1989. Coniferin, a biochemical indicator of commitment to tracheid differentiation in conifers. Can. J. Bot. 67: 2663-2668.
Savidge, R.A. 1990. Phytohormone regulation of secondary xylem development. In IUFRO XIX World Congress (Montreal), Proc. Div. 5, Forestry Canada: 65-76.

Savidge, R.A. 1991. Seasonal cambial activity in Larix laricina saplings in relation to endogenous indol-3-ylacetic acid, sucrose, and coniferin. Forest Science 37: 953-958.

Savidge, R.A. \& J.L. Farrar. 1984. Cellular adjustments in the vascular cambium leading to spiral grain formation in conifers. Can. J. Bot. 62: 2872-2879.

Savidge, R.A., G.M.C. Mutumba, J.K. Heald \& P.F. Wareing. 1983. Gas chromatography - mass spectroscopy identification of 1-aminocyclopropane-1-carboxylic acid in compression wood vascular cambium of Pinus contorta Dougl. Plant Physiol. 71: 434-436.

Savidge, R.A. \& P.F. Wareing. 1981a. A tracheid-differentiation factor from pine needles. Planta 153: 395-404.

Savidge, R.A. \& P.F. Wareing. 1981b. Plantgrowth regulators and the differentiation of vascular elements In: J.R. Barnett (ed.), Xylem cell development: 192-235. Castle House Publ., Tunbridge Wells, Kent, England.

Schenk, R.U. \& A.C. Hildebrandt. 1972. Medium and techniques for induction and growth of monocotyledonous and dicotyledonous plant cell cultures. Can. J. Bot. 50: 199-204.

Sheriff, D.W. 1983. Control by indole-3acetic acid of wood production in Pinus radiata $D$. Don segments in culture. Aust. J. Plant Physiol. 10: 131-135.

Sussex, I.M. \& M.E. Clutter. 1959. Seasonal growth periodicity of tissue explants from woody perennial plants in vitro. Science 129: 836-837.

Wacek, A. von, O. Härtel \& S. Meralla. 1954. Über die Wirkung von Coniferinzusatz auf die Verholzung von Fichtengewebe bei Kultur in vitro. Holzforschung 8: 65-67.

White, P.R. 1954. The cultivation of animal and plant cells. Ronald Press, New York.

Zajączkowski, S. 1973. Auxin stimulation of cambial activity in Pinus silvestris. I. The differential cambial response. Physiol. Plant. 29: 281-287. 